\title{
Effects of storage culture media, temperature and duration on human adipose-derived stem cell viability for clinical use
}

\author{
YIN-DI WU ${ }^{1 *}$, MENG LI $^{1 *}$, XUAN LIAO ${ }^{1}$, SHENG-HONG LI $^{1}$, JIAN-XIN YAN $^{1}$, \\ LEI FAN ${ }^{2}$, WEN-LI SHE ${ }^{1}$, JIAN-XIN SONG ${ }^{3}$ and HONG-WEI LIU ${ }^{1}$ \\ ${ }^{1}$ Department of Plastic Surgery, The First Affiliated Hospital of Jinan University, Key Laboratory of Regenerative Medicine, \\ Ministry of Education; ${ }^{2}$ Department of Orthopedics, Third Affiliated Hospital of Sun Yat-Sen University, \\ Guangzhou, Guangdong 510630; ${ }^{3}$ Department of Plastic Surgery, Changhai Hospital, \\ The Second Military Medical University, Shanghai 200433, P.R. China
}

Received January 21, 2018; Accepted November 8, 2018

DOI: $10.3892 / \mathrm{mmr} .2019 .9842$

\begin{abstract}
Adipose-derived stem cells (ADSCs) are mesenchymal stem cells that are often used in regenerative medicine. Maintaining ADSC viability is important, as this optimizes the curative effects of cell therapy. However, the optimal conditions for cell viability preservation remain unknown. The present study aimed to acquire a better protocol for ADSC storage by comparing the effects of various solutions and temperatures for ADSC preservation, in order to suggest the most effective methods of short-term ADSC preservation for clinical use. ADSCs from passage 2 were suspended in solutions comprising $0.9 \% \mathrm{NaCl}, 10 \%$ human serum (HS) or $10 \%$ platelet-rich plasma (PRP). Suspended cells were maintained at $4^{\circ} \mathrm{C}$ or room temperature $\left(\sim 26^{\circ} \mathrm{C}\right)$ for 2,4 and $6 \mathrm{~h}$. The differentiation capacity, apoptosis and proliferation of ADSCs were determined by oil red O/alizarin red S staining, flow cytometry, and a cell counting kit-8 cell proliferation assay, respectively. In addition, reverse transcription-quantitative polymerase chain reaction and western blot analysis was performed. The results revealed that proliferation of ADSCs decreased with time. The optimal time for ADSC use was $\sim 2 \mathrm{~h}$, and $4 \mathrm{~h}$ was determined to be the latest time that ADSCs should be used. The 10\% HS group had the highest survival rate, followed by the $10 \%$ PRP group; these two groups had higher survival rates than the $0.9 \% \mathrm{NaCl}$ group $(\mathrm{P}<0.05)$. $\mathrm{HS}$ and $\mathrm{PRP}$ at $4^{\circ} \mathrm{C}$ enhanced the ADSC proliferation rate $(\mathrm{P}<0.05)$, although the difference between these two groups was insignificant
\end{abstract}

Correspondence to: Professor Hong-Wei Liu, Department of Plastic Surgery, The First Affiliated Hospital of Jinan University, Key Laboratory of Regenerative Medicine, Ministry of Education, 601 Whampoa Road West, Guangzhou, Guangdong 510630, P.R. China E-mail: liuhongwei0521@hotmail.com

\section{${ }^{*}$ Contributed equally}

Key words: mesenchymal stromal cells, adipose tissue, cell proliferation, cell survival, methods, utilization, preservation
$(\mathrm{P}>0.05)$. In conclusion, the optimal time to use ADSCs was $<2 \mathrm{~h}$, and should not exceed $4 \mathrm{~h}$. It was recommended that, for the transportation and short-term storage of ADSCs during clinical use, they should be stored with $10 \% \mathrm{HS}$ at $4^{\circ} \mathrm{C}$ to maintain ADSC viability. In addition, this was a cost-effective and safe method.

\section{Introduction}

As a type of mesenchymal stromal cell, adipose-derived stem cells (ADSCs) are characterized by their ability to self-renew and differentiate into multiple cell lineages (1). ADSCs are obtained from white or brown adipose tissue (2). Advantages of ADSCs are that they are abundant, collection results in minimal morbidity, they may differentiate into multiple cell lineages, and can be transplanted safely and effectively (3). It is generally accepted that adipose tissue contains multipotent progenitor cells (4). In addition, it comprises a useful and clinically important cell population called the stromal vascular fraction (SVF). SVF may be used directly or cultured as ADSCs $(2,5,6)$. ADSCs are abundantly sourced and readily attained. SVF/ADSCs may be collected for clinical use by harvesting adipose tissue, digesting type I collagen enzymes, and removing red blood cells. ADSCs have been extensively applied in various clinical fields, including treatment for immune disorders, tissue degeneration and ischemic conditions, as well as soft tissue, craniofacial tissue and cardiovascular tissue regeneration $(2,7)$. Considering their clinical characteristics and high demand, maintaining ADSC viability during transit or prior to clinical application is a wide concern, and the present study focused on methods for preserving ADSCs.

The primary methods for in vitro storage include $4^{\circ} \mathrm{C}$ non-frozen preservation, $-80^{\circ} \mathrm{C}$ cryopreservation and $-196^{\circ} \mathrm{C}$ programmed cryopreservation in liquid nitrogen. Gonda et al (8) demonstrated that adipocytes may be optimally preserved for viability by cooling to sub-zero temperatures in liquid nitrogen for 6 months with a set preservation protocol. Following long-term cryopreservation, the proliferation and multiple differentiation capacities of human ADSCs are not lost (9). Matsumoto et al (10) determined oil volume ratio, 
glycerol-3-phosphate dehydrogenase activity and cell-surface marker expression via scanning electron microscopy to assess the viability of ADSCs at room temperature (RT) and at $4^{\circ} \mathrm{C}$. Furthermore, it was reported that adipose tissue should be stored promptly, as storage overnight at $4^{\circ} \mathrm{C}$ results in no evident loss or alteration in the biological properties or yield of ADSCs (10). However, it has also been indicated that low temperatures may irreversibly damage the ADSC membrane $(11,12)$. In this regard, an appropriate protection medium should be adopted when freezing cells, such as dimethyl sulfoxide (DMSO). To mitigate this damage, Bunnell et al (13) stored the cells in a specialized container. This allowed the temperature to be lowered at a rate of $1^{\circ} \mathrm{C} / \mathrm{min}$ until $-80^{\circ} \mathrm{C}$ was reached, and the cells were stored overnight. The following day, the cells were transferred to liquid nitrogen (13). Thus far, the majority of studies have been concerned with the long-term preservation of stem cells. For stem cells intended for clinical application, the current methods of preservation are inadequate, as human ADSC transplantation requires higher standards of security, survival and proliferation ability. In addition to the temperature, the preservation medium is also of critical significance. Several reports have concluded that an environment that mimics that of the native cell, containing $0.9 \% \mathrm{NaCl}, 5 \%$ glucose and albumin or human serum (HS), is the most appropriate for cell survival (14). Other preservation media have also been studied, such as DMSO; however, the clinical use of DMSO causes diverse problems, including leukoencephalopathy, nausea, vomiting and potential renal function decrease (15). Liu et al (16) determined that 10-12.5\% of human platelet-rich plasma (hPRP) resulted in the best outcome in bone formation tests, and involved injecting a mixture of ADSCs, hPRP and injectable tissue engineering bone into a nude mouse. As demonstrated by Shafaei et al (17), HS creates a better micro-environment for cell survival than fetal bovine serum (FBS).

For the clinical application of ADSCs, short-term preservation is more crucial than other time frames. Thus, identifying a safer temperature, more suitable medium and appropriate time frame is of crucial importance. In the present study, the effect of different temperatures $\left[4^{\circ} \mathrm{C}\right.$ and $\left.\mathrm{RT}\left(\sim 26^{\circ} \mathrm{C}\right)\right]$ and three types of preservation media (10\% PRP, $10 \%$ HS and $0.9 \%$ normal saline) on ADSCs was tested to determine optimal time and storage conditions. Survival, proliferation and differentiation abilities of ADSCs were investigated under these various conditions.

\section{Materials and methods}

Ethics statement. The protocol of the present study was approved by the Ethics Committee of The First Affiliated Hospital of Jinan University (Guangzhou, China). Informed consent was obtained from all subjects prior to the current study. The fat tissue used in the present study came from a 65 -year-old woman and the blood used in the present study came from a 26-year-old woman.

Preparation and activation of PRP. PRP was prepared following the method reported by Jalowiec et al (18). In brief, blood samples from a 26-year-old man were collected in anti-agglutination tubes and centrifuged twice at $200 \mathrm{x} \mathrm{g}$ for
$10 \mathrm{~min}$ and $400 \mathrm{xg}$ for $15 \mathrm{~min}$ at RT to collect adequate platelets. The supernatant platelet-poor plasma was transferred to another tube and used as a diluent when necessary. Factoring in the PRP platelet concentration, which was counted in a Malassez counting chamber (EMD Millipore, Billerica, MA, USA ), a minimum value of $800 \times 10^{9} / 1$, and a maximum value of $1,200 \times 10^{9} / 1$, was expected for the final PRP platelet concentration (the platelet concentration of PRP is $\sim 5$ times that of whole blood) (19). A concentration of $862 \times 10^{9} / 1$ PRP was attained. The product was activated with $10 \%$ calcium gluconate and subsequently stored at $4^{\circ} \mathrm{C}$ overnight. Prior to application, the product was centrifuged at $3,000 \mathrm{x} \mathrm{g}$ for $15 \min (\mathrm{RT})$.

Preparation of HS. HS was prepared following the method described by Freymann et al (20). Blood samples from the same person were collected in dry blood collecting tubes. Once the blood had coagulated, the serum was isolated from the entire blood clot by centrifugation at 2,000 $\mathrm{x}$ g for $10 \mathrm{~min}$ at RT. The PRP and HS were stored at $-20^{\circ} \mathrm{C}$ and thawed prior to application.

Cell isolation and culture. Isolation and culture of ADSCs was partially performed using the standard protocols of Bura et al (21) and Guo et al (22). Permission and a signed consent to participate from the Institutional Review Board of Medical Science (Jinan University, Guangzhou, China) was obtained prior to the collection of $100 \mathrm{ml}$ abdominal subcutaneous fat from a 65 -year-old patient in November 2016. The adipose tissue was digested with $0.2 \%$ collagenase I (Biochrom $\mathrm{GmbH}$, Berlin, Germany) for $30 \mathrm{~min}$ at $37^{\circ} \mathrm{C}$, centrifuged for $10 \mathrm{~min}$ at $300 \mathrm{x} \mathrm{g}(\mathrm{RT})$ and filtered with a $100 \mu \mathrm{m}$ mesh filter (neoLab Migge GmbH, Heidelberg, Germany). $\mathrm{NaCl}(0.3 \%)$ was used to remove the red blood cells prior to transfer of cells into culture medium including Dulbecco's Modified Eagle's Medium (DMEM; Gibco; Thermo Fisher Scientific, Inc., Waltham, MA, USA) containing $10 \%$ fetal calf serum (Gibco; Thermo Fisher Scientific, Inc.), $1 \% 100 \mathrm{U} / \mathrm{ml}$ penicillin and $100 \mu \mathrm{g} / \mathrm{ml}$ streptomycin, and culture in $5 \% \mathrm{CO}_{2}$ at $37^{\circ} \mathrm{C}$. The culture medium was changed at 3 day intervals. Primary cells were cultured for $\sim 10$ days and defined as 'passage 0 '. ADSCs of passage 2 which were cultured at culture medium and passaged twice, then prepared for subsequent experimentation.

Cell phenotype identification. To characterize the phenotype of ADSCs, the surface markers were determined, using flow cytometry as previously described (10). Briefly, ADSCs were incubated with Thy-1 cell surface antigen (CD90, catalog number: 561970), protein tyrosine phosphatase, receptor type C (CD45, catalog number: 555482), CD34 molecule (CD34, catalog number: 550761), integrin subunit $\beta 1$ (CD29, catalog number: 557332), endoglin (CD105, catalog number: 561441), CD44 antigen (CD44, catalog number: 555478) and major histocompatibility complex, class II DR (HLA-DR, catalog number: 555812) antibodies (BD Biosciences, Franklin Lakes, $\mathrm{NJ}, \mathrm{USA}$ ) at $4^{\circ} \mathrm{C}$ for $30 \mathrm{~min}$ in the dark. Excess antibody was removed, cells were washed twice with PBS and $300 \mu 1$ fixative solution was added. Flow cytometric analyses were performed with FlowJo version 7.6.1 (FlowJo LLC, Ashland, OR, USA). 
In vitro osteogenic differentiation. ADSCs were seeded onto 24-well plates at a density of $1 \times 10^{4}$ cells/well. Following culture for $24 \mathrm{~h}$ in $10 \%$ FBS medium (Gibco; Thermo Fisher Scientific, Inc.) $37^{\circ} \mathrm{C}$, cells were cultured in osteogenic differentiation medium at $37^{\circ} \mathrm{C}$, composed of standard medium supplemented with FBS, penicillin-streptomycin, glutamine, ascorbate, $\beta$-glycerophosphate and dexamethasone (Cyagen Biosciences, Inc., Santa Clara, CA USA). During osteogenic induction, the medium was changed every three days. After 14 days of in vitro osteogenic induction, cells were washed twice with PBS and subsequently fixed with $10 \%$ neutral formaldehyde for $30 \mathrm{~min}$ at RT. Fixed cells were stained $4 \mathrm{~min}$ at $37^{\circ} \mathrm{C}$ with $0.1 \%$ alizarin red dye to visualize calcium deposition $(23,24)$. The stained plates were air-dried for $2 \mathrm{~min}$ and observed under a light microscope (magnification, x100).

In vitro adipogenic differentiation. ADSCs were seeded onto 24-well plates at a density of $1 \times 10^{4}$ cells/well following culture for $24 \mathrm{~h}$ at $37^{\circ} \mathrm{C}$ in DMEM with $10 \%$ FBS. Cells were subsequently placed in adipogenic differentiation medium (Cyagen Biosciences, Inc.). During adipogenic differentiation, the medium was changed every three days. Following culture for 14 days, cells were washed with PBS and fixed with $10 \%$ neutral formaldehyde for $30 \mathrm{~min}$ at RT. Fixed cells were stained with $0.5 \%$ oil red $\mathrm{O}$ dye for $30 \mathrm{~min}$ at $37^{\circ} \mathrm{C}(25,26)$. Cells were washed again in PBS and observed under a light microscope (magnification, x100).

Experimental groups. ADSCs were placed in six $15 \mathrm{ml}$ tubes at $5 \times 10^{5}$ cells/tube and were numbered 1-6. The following media were added to the tubes: i) $0.5 \mathrm{ml} 0.9 \% \mathrm{NaCl}$, ii) $0.5 \mathrm{ml}$ $10 \%$ HS, iii) $0.5 \mathrm{ml} 10 \%$ PRP, iv) $0.5 \mathrm{ml} 0.9 \% \mathrm{NaCl}$, v) $0.5 \mathrm{ml}$ $10 \% \mathrm{HS}$ and vi) $0.5 \mathrm{ml} 10 \% \mathrm{PRP}$. Tubes $1-3$ were stored at $4^{\circ} \mathrm{C}$, while tubes 4-6 were stored at RT. Following a 2, 4 and $6 \mathrm{~h}$ culture, cell survival, apoptosis, proliferation and differentiation abilities were determined.

Cell proliferation assay. Cell proliferation was assessed with a Cell Counting Kit-8 (CCK8) assay (Dojindo Molecular Technologies, Inc., Kumamoto, Japan). The optical density (OD) values obtained indirectly report on cell proliferation. ADSCs from each group were seeded onto 96-well plates at a density of $3 \times 10^{3}$ cells/well ( 5 parallel wells were seeded for each group). The cells were cultured at $37^{\circ} \mathrm{C}$ for $24 \mathrm{~h}$, rinsed with PBS and mixed with $10 \mu 1 \mathrm{CCK} 8$ in $100 \mu 1 \mathrm{DMEM}$ at $37^{\circ} \mathrm{C}$ until the medium turned orange. The absorbance of each well was detected by a microplate reader at a wavelength of $450 \mathrm{~nm}$. The OD value was recorded, and the difference was analyzed using statistical methods (22).

Cell survival assay. Cell suspension (500 $\mu \mathrm{l})$ from each group was placed into a flow tube. Propidium iodide (PI; $5 \mu \mathrm{l}$ ) was added to the flow tube with $5 \mu \mathrm{l}$ Annexin V-FITC stain and mixed for $10 \mathrm{~min}$ in the dark at RT. The values of the side scatter, which represented the entire cell population, and the FL3 channel, which represented living cells, were recorded according to the detection of Annexin V-FITC/PI double staining cell apoptosis kit (KeyGEN) by flow cytometry. Data were analyzed with FlowJo version 7.6.1 (FlowJo LLC, Ashland, OR, USA).
Semi-quantification of in vitro osteogenic differentiation. ADSCs from each group were seeded onto 96-well plates at a density of $3 \times 10^{3}$ cells/well (5 parallel wells were seeded for each group) and maintained in osteogenic differentiation medium for 14 days. Cultivation procedures and alizarin red $\mathrm{S}$ dye staining was performed according to the protocol described above. In brief, the 96-well plates were decolored using $100 \mu \mathrm{l} 10 \%$ hexadecylpyridinium chloride for $30 \mathrm{~min}$ at $\mathrm{RT}$, and the OD value was detected with a microplate reader at a wavelength of $562 \mathrm{~nm}$ to perform a semi-quantitative analysis of osteogenic differentiation, as described previously $(27,28)$.

Semi-quantification of in vitro adipogenic differentiation. ADSCs from each group were seeded onto 96-well plates at a density of $3 \times 10^{3}$ cells/well ( 5 parallel wells were seeded for each group) and cultured in adipogenic differentiation medium, as described above, prior to observation under a light microscope. Cells in the 96-well plates were subsequently decolored with $100 \mu 1100 \%$ isopropanol for $60 \mathrm{~min}$, and the OD value was detected using a microplate reader at a wavelength of $510 \mathrm{~nm}$ to semi-quantitatively analyze adipogenic differentiation (26).

$R N A$ isolation and reverse transcription-quantitative polymerase chain reaction $(R T-q P C R)$. Total RNA from each group was isolated using TRIzol reagent (Thermo Fisher Scientific, Inc.) according to the manufacturer's instructions. RNA concentration was determined using a spectrophotometer (Bio-Rad Laboratories, Inc., Hercules, CA, USA). RNAs with 260/280 ratios between 1.7 and 2.1 were used. cDNA was synthesized according to the protocol accompanying the PrimeScript ${ }^{\circledR}$ RT Master Mix kit (Takara Biotechnology Co., Ltd., Beijing, China) using $500 \mathrm{ng}$ total RNA, and the reaction conditions were $25^{\circ} \mathrm{C}$ for start, $37^{\circ} \mathrm{C}$ for $15 \mathrm{mins}, 85^{\circ} \mathrm{C}$ for $5 \mathrm{sec}$ and then resting at $4^{\circ} \mathrm{C}$. The primers for each gene were designed using the PrimerBank (29). RT-PCR was performed using $2 \mu \mathrm{l}$ cDNA. PCR conditions were: $95^{\circ} \mathrm{C}$ for $30 \mathrm{sec}$ for denaturation, $95^{\circ} \mathrm{C}$ for $5 \mathrm{sec}$ (45 cycles) for amplification and at $60^{\circ} \mathrm{C}$ for $20 \mathrm{sec}$. The RNA analysis employed SYBR Green (Roche Diagnostics, Indianapolis, IN, USA). Data were quantified using the $2^{-\Delta \Delta \mathrm{Cq}}$ method (30) by normalizing the expression of the target genes to the housekeeping gene, GAPDH. The values were described as the expression of the target genes, including runt related transcription factor 2 (RUNX2), SRY-box 9 (SOX9) and sp7 transcription factor (osterix) for osteogenic differentiation, as well as fatty acid-binding protein 4 (FABP4), peroxisome-proliferator-activated receptor (PPAR) $\gamma$ and CCAAT/enhancer-binding protein (CEBP) $\alpha$ for adipogenic differentiation. All primer sequences are listed in Table I.

Western blot analysis of osteocalcin and PPAR $\gamma$. Following osteogenic and adipogenic differentiation, ADSCs from each group were lysed using radioimmunoprecipitation assay buffer (Dalian Meilun Biotechnology Co., Ltd., Dalian, China). Equal quantities of total protein $(25 \mu \mathrm{g})$ from each group were separated by $12 \%$ SDS-PAGE (Beyotime Institute of Biotechnology, Shanghai, China). The proteins were subsequently transferred onto a polyvinylidene fluoride membrane. Membranes were blocked with $5 \%$ non-fat milk for $1 \mathrm{~h}$ at RT prior to incubation with mouse monoclonal anti-PPAR $\gamma$ (diluted with 5\% 
Table I. Primer sequences used for reverse transcription-quantitative polymerase chain reaction.

\begin{tabular}{lll}
\hline Gene & \multicolumn{1}{c}{ Forward $\left(5^{\prime} \rightarrow 3^{\prime}\right)$} & \multicolumn{1}{c}{ Reverse $\left(3^{\prime} \rightarrow 5^{\prime}\right)$} \\
\hline RUNX2 & TGGCAGTCACATGGCAGATT & CTTGGGTGGGTGGAGGATTC \\
SOX9 & GAGGAAGTCGGTGAAGAACGG & CCCTCTCGCTTCAGGTCAG \\
Osterix & GTAGGACTGTAGGACCGGA & GCCATAGTGAACTTCCTCCTCA \\
FABP4 & TGGGCCAGGAATTTGACGAA & GCGAACTTCAGTCCAGGTCA \\
PPAR $\gamma$ & GCAAACCCCTATTCCATGCT & CCACGGAGCTGATCCCAAAG \\
CEBP $\alpha$ & GACTAGGAGATTCCGGTGCC & GCATTGGAGCGGTGAGTTTG \\
GAPDH & GCTAAGGCTGTGGGGAAAGT & TCAGCAGCAGCCTTCACTAC
\end{tabular}

RUNX2, runt-related transcription factor 2; SOX9, SRY-box 9; osterix, sp7 transcription factor; FABP4, fatty acid-binding protein 4; PPAR $\gamma$, peroxisome-proliferator-activated receptor $\gamma$; CEBP $\alpha$, CCAAT/enhancer binding protein $\alpha$.
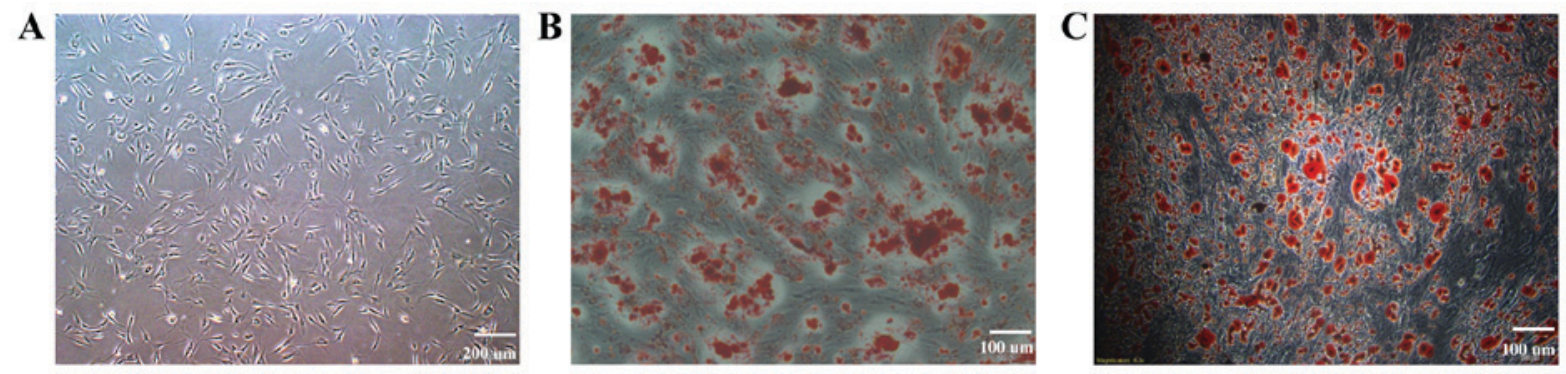

Figure 1. ADSC differentiation identification. (A) Normal ADSCs from P2 were cultured in Dulbecco's modified Eagle's medium with $10 \%$ fetal bovine serum for 2 days. (B) ADSCs from P2 cultured in osteogenic differentiation medium for 14 days and observed by microscopy following alizarin red S staining. (C) ADSCs from P2 cultured in adipogenic differentiation medium for 14 days and observed by microscopy following oil red O staining. P2, passage 2; ADSC, adipose-derived stem cells.

BSA to 1:10,000, cat. no. 41928; Abcam, Cambridge, UK) and anti-osteocalcin antibodies (1:10,000, cat. no. 13421; Abcam), followed by incubation with goat-anti-mouse horseradish peroxidase-conjugated secondary antibody (Genetech Co., Ltd., Shanghai, China). The levels of osteocalcin and PPAR $\gamma$ were normalized to those of GAPDH (1:10,000, cat. no. 9482; Abcam). ImageJ version 2.0 software (National Institutes of Health, Bethesda, MD, USA) was used for densitometry.

Statistical analysis. All values were reported as the mean \pm standard error of the mean ( $n=5 /$ group). Data were analyzed using Student' s t-test or one-way analysis of variance followed by the standard Tukey test for post-hoc analysis using SPSS version 13.0 (SPSS, Inc., Chicago, IL, USA). $\mathrm{P}<0.05$ was considered to indicate a statistically significant difference.

\section{Results}

Cell identification. ADSCs from P2 were spindle-shaped (Fig. 1A), and the differentiation identification results are presented in Fig. 1B and C. Cells differentiated in osteogenic or adipogenic medium were stained with alizarin red (Fig. 1B) or oil red O (Fig. 1C), which detected calcium salt or lipid droplets, respectively. The phenotype identification results (Fig. 2A) revealed that ADSCs were positive for CD44 (Fig. 2B), CD105 (Fig. 2C), CD29 (Fig. 2D), and CD90 (Fig. 2E), expressed low levels of CD45 (Fig. 2F), and were negative for CD34 (Fig. 2G) and HLA-DR (Fig. 2H).
Cell proliferation is dependent on preservation temperature, duration and medium. The results of the CCK8 cell proliferation assay revealed that the proliferative ability of each group declined with time (Fig. 3). Cells in the same media when stored at $4^{\circ} \mathrm{C}$ had increased proliferation compared with the RT group (Fig. 3A). In addition, the data demonstrated that the 10\% PRP and $10 \%$ HS groups had higher OD values compared with the $0.9 \% \mathrm{NaCl}$ group (Fig. 3B); however, the difference between 10\% PRP and $10 \%$ HS was not statistically significant. In addition, the storage of cells at $4^{\circ} \mathrm{C}$ in $10 \% \mathrm{PRP}$ or $10 \% \mathrm{HS}$ facilitated cell proliferation for up to $4 \mathrm{~h}$. There was an obvious decline between 4 and $6 \mathrm{~h}$, whereas the difference between 2 and $4 \mathrm{~h}$ was relatively similar (Fig. 3C). Therefore, cells should be used earlier than $4 \mathrm{~h}$ and stored at $4^{\circ} \mathrm{C}$ to maintain proliferative ability.

Cell survival is dependent on preservation temperature, duration and medium. The survival rates of all groups declined with time (Fig. 3D). When comparing the two temperatures, $4{ }^{\circ} \mathrm{C}$ improved ADSC preservation when stored in $0.9 \%$ $\mathrm{NaCl}$, as evidenced by the higher survival rate (Fig. 3E). Furthermore, the data demonstrated that groups stored in $10 \%$ PRP and $10 \%$ HS had higher survival rates, compared with the $0.9 \% \mathrm{NaCl}$ group (Fig. $3 \mathrm{~F}$ ). There was a common decline among ADSCs in different media at different times; however, ADSCs maintained a stable survival rate under $2 \mathrm{~h}$. The survival rate of ADSCs stored at $4^{\circ} \mathrm{C}$ in $0.9 \% \mathrm{NaCl}$ was $63.23 \%$ (Fig. 4A). ADSCs stored at $4^{\circ} \mathrm{C}$ in $10 \%$ HS had the best survival rate of $89.18 \%$ (Fig. 4B). ADSCs stored at $4^{\circ} \mathrm{C}$ in $10 \%$ 

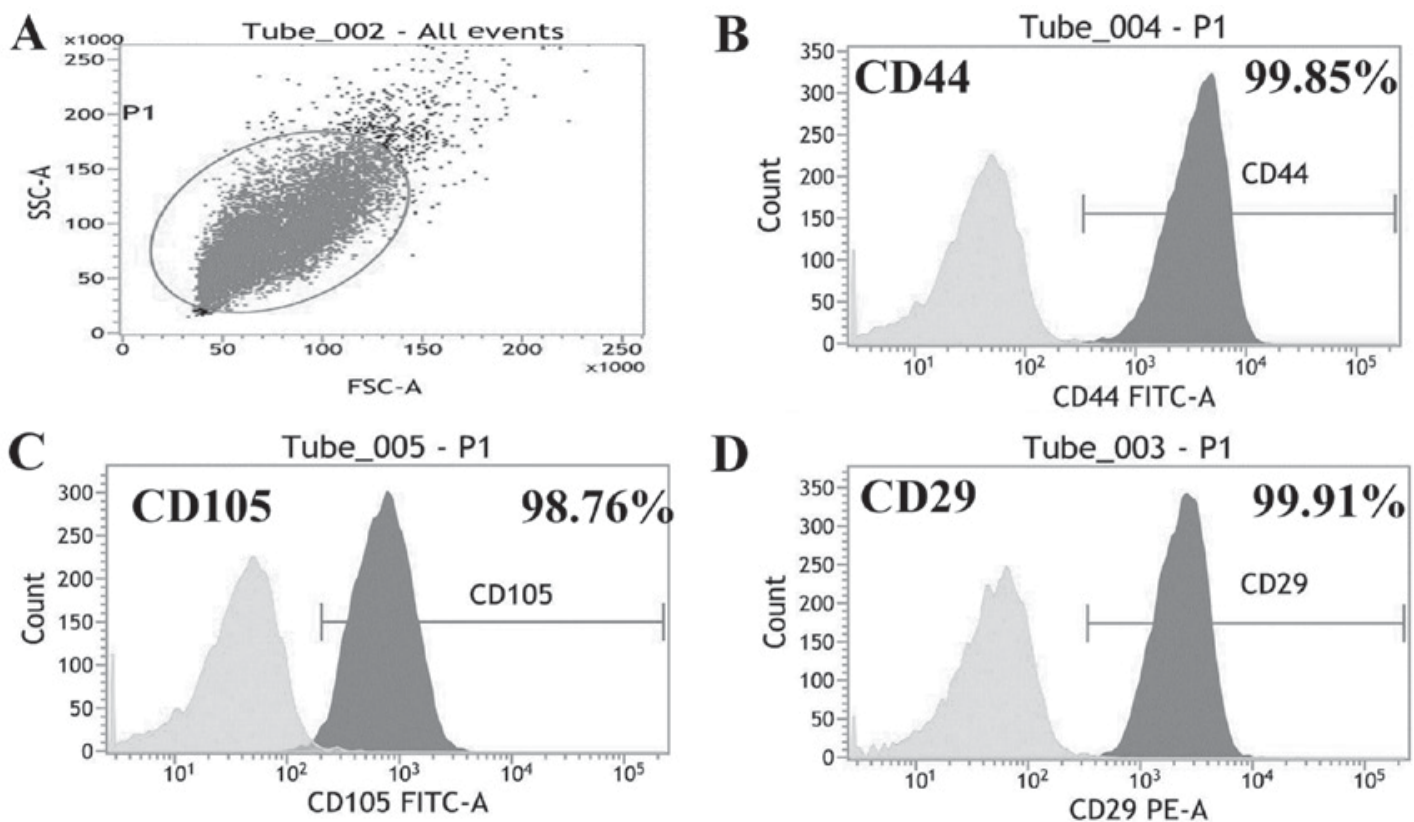

D
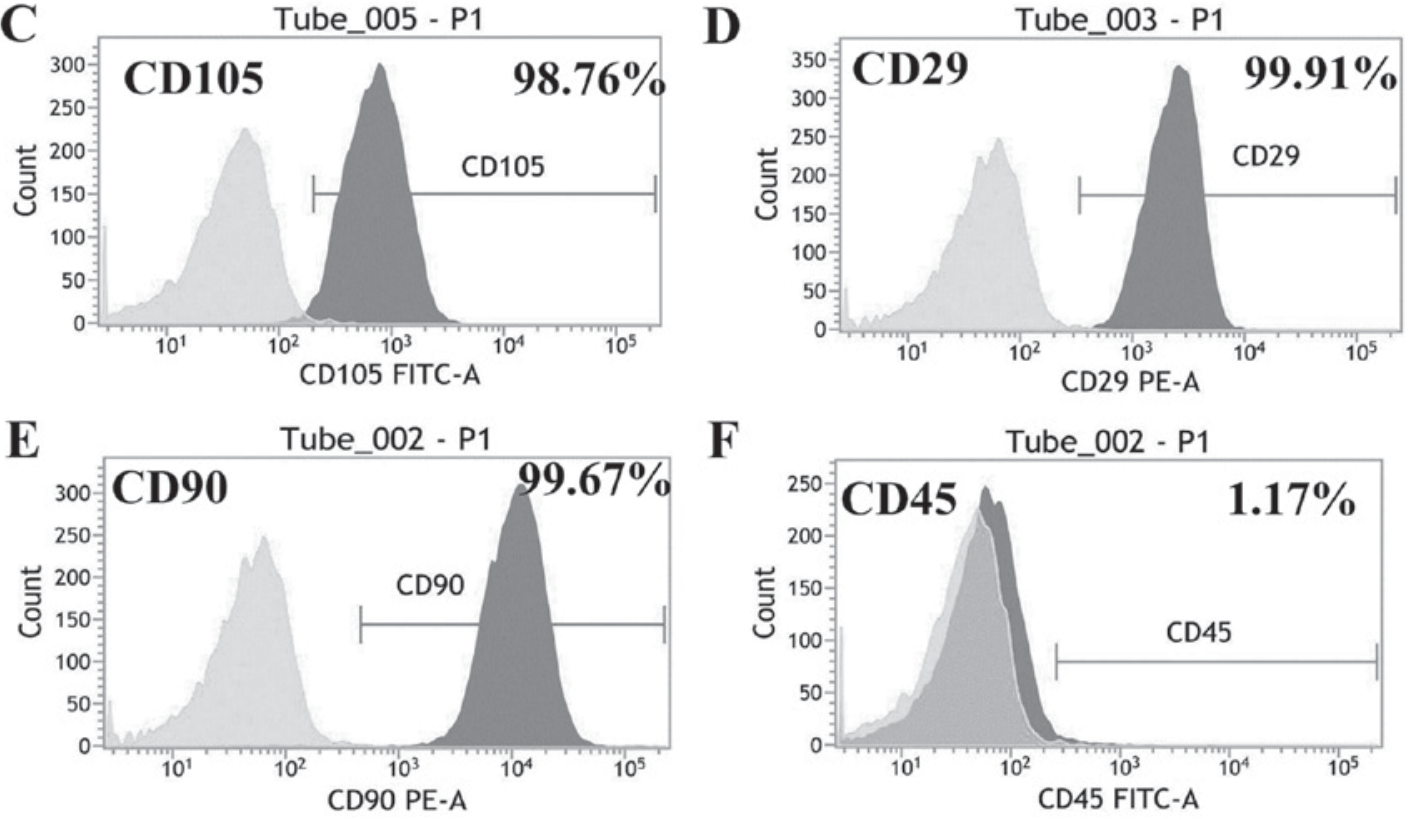

$\mathbf{F}$
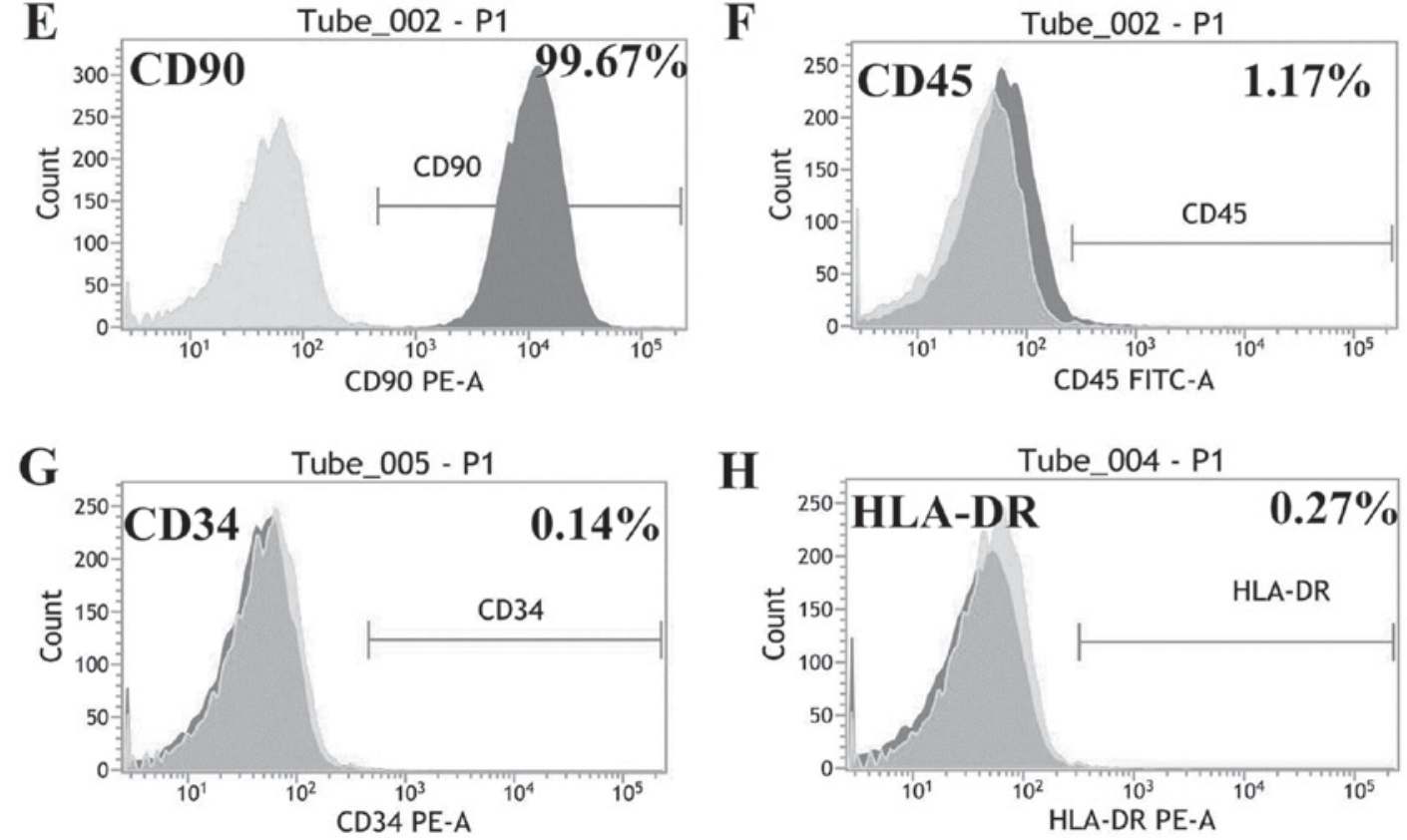

Figure 2. ADSC phenotype identification. (A) Phenotypes were identified by flow cytometry. (B) ADSCs were positive for CD44, (C) CD105, (D) CD29 and (E) CD90. (F) Low levels of CD45 were expressed, and ADSCs were negative for (G) CD34 and (H) HLA-DR. ADSC, adipose-derived stem cells; CD90, Thy-1 cell surface antigen; CD45, protein tyrosine phosphatase, receptor type C; CD34, CD34 molecule; CD29, integrin subunit $\beta$ 1; CD105, endoglin; CD44, CD44 antigen; HLA-DR, major histocompatibility complex, class II DR

PRP had the next highest survival rate of $80.81 \%$ (Fig. 4C), whereas the survival rate of ADSCs without treatment was $92.16 \%$ (Fig. 4D). In conclusion, to maintain a survival rate above $80 \%$, ADSCs should be used within $2 \mathrm{~h}$ and stored for no longer than $4 \mathrm{~h}$. These results demonstrated that $10 \% \mathrm{HS}$ was the optimum medium.

ADSC differentiation capacity decreases when stored at RT. The experimental results revealed that the osteogenic (Fig. 5A) and adipogenic (Fig. 5B) differentiation of cells stored at $4^{\circ} \mathrm{C}$ was more successful compared with the cells stored at RT. Thus, compared with $\mathrm{RT}, 4^{\circ} \mathrm{C}$ is a more suitable environment for the preservation of ADSCs $(\mathrm{P}<0.05)$.
ADSC differentiation capacity decreases over time. It was demonstrated that the osteogenic (Fig. 6A) and adipogenic (Fig. 6B) differentiation capacity of ADSCs decreased over time, and there were statistically significant differences between each group. It was concluded that ADSCs should be utilized as soon as possible.

ADSC differentiation capacity decreases when stored in $0.9 \% \mathrm{NaCl}$. It was determined that $10 \% \mathrm{PRP}$ and $10 \% \mathrm{HS}$ were more optimal media for osteogenic and adipogenic differentiation, compared with $0.9 \% \mathrm{NaCl}$ medium $(\mathrm{P}<0.05$; Fig. 7A). However, there was no statistically significant difference between the 10\% PRP and 10\% HS groups for adipogenic 

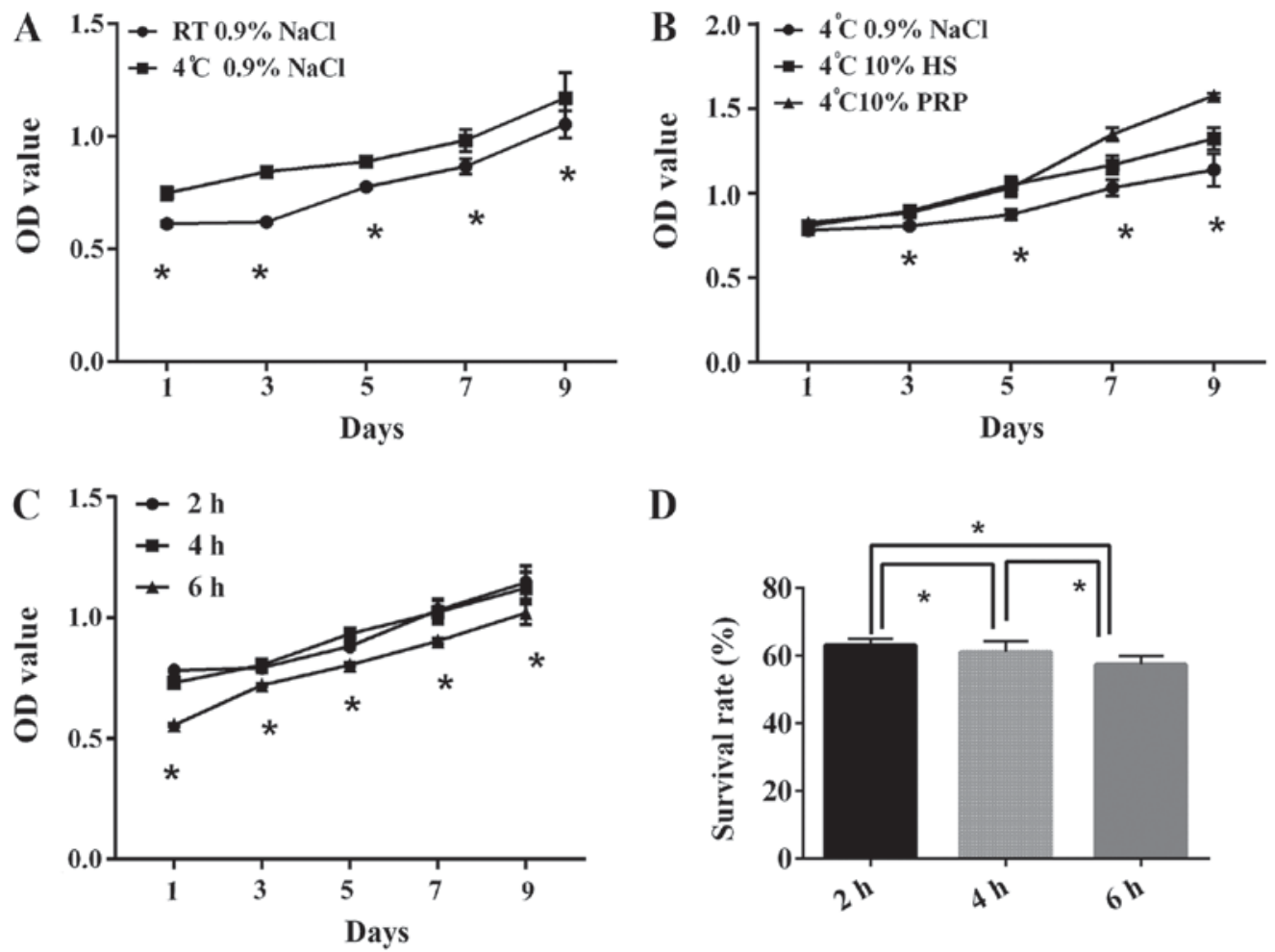

D

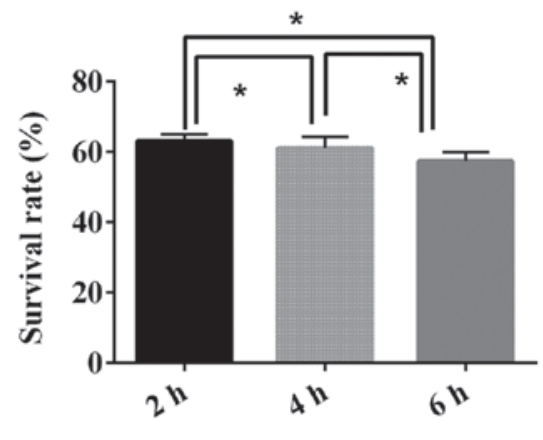

$\mathbf{E}$

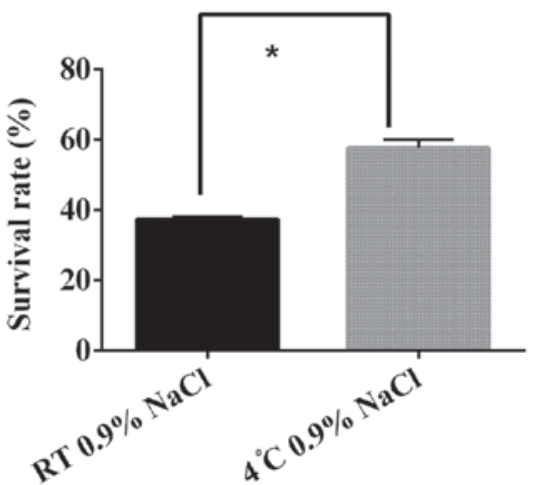

$\mathbf{F}$

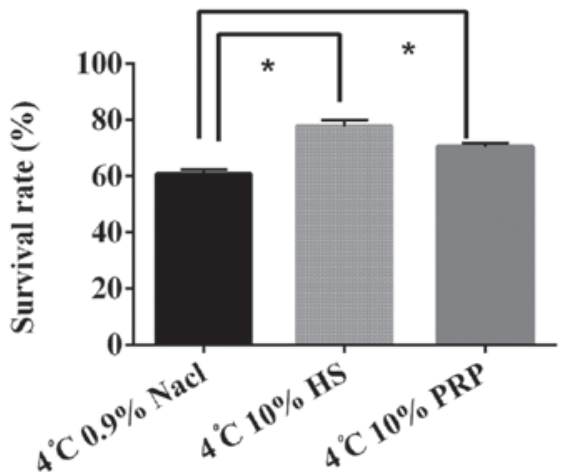

Figure 3. Comparison of ADSC proliferative ability when preserved in different conditions. ADSCs from different groups were observed following the addition of $10 \mu \mathrm{l}$ cell counting kit 8 reagent, and the OD value was measured. (A) ADSC suspended in $0.9 \% \mathrm{NaCl}$ were preserved at RT and $4^{\circ} \mathrm{C}$ for $2 \mathrm{~h}$. (B) $\mathrm{ADSCs}$ suspended in three types of medium for $2 \mathrm{~h}$ at $4^{\circ} \mathrm{C}$. (C) ADSCs suspended in $0.9 \% \mathrm{NaCl}$ were preserved at $4^{\circ} \mathrm{C}$ for 2,4 and $6 \mathrm{~h}$. (D) Following the addition of $5 \mu 1$ Annexin V-FITC/PI staining, ADSCs were analyzed and the SS and FL3 values were recorded, according to the detection of Annexin V-fluorescein isothiocyanate/PI. The survival rate of ADSCs suspended in $0.9 \% \mathrm{NaCl}$ at $4^{\circ} \mathrm{C}$ for 2,4 and $6 \mathrm{~h}$ is presented. (E) Survival rate $\mathrm{ADSCs}$ preserved at RT and $4{ }^{\circ} \mathrm{C}$ in $0.9 \% \mathrm{NaCl}$ for $6 \mathrm{~h}$. (F) Survival rate of ADSCs suspended in three types of medium for $4 \mathrm{~h}$ at $4^{\circ} \mathrm{C}$. ${ }^{*} \mathrm{P}<0.05$. ADSCs, adipose-derived stem cells; OD, optical density; PI, propidium iodide; RT, temperature; HS, human serum; PRP, platelet-rich plasma.

differentiation (Fig. 7B). To maintain a higher differentiation rate, $10 \%$ HS or $10 \%$ PRP should be used as the suspension media for the short-term preservation of ADSCs.

Expression of osteogenic and adipogenic-associated genes is altered by ADSC preservation temperature, medium and duration. The differential expression of RUNX2, SOX9, osterix, FABP4, PPAR $\gamma$, and CEBP $\alpha$ for different temperatures and over time are presented in Fig. 8. Similar trends were observed; the expression of genes associated with osteogenic and adipogenic differentiation was lower for cells stored at RT than for those stored at $4^{\circ} \mathrm{C}$. Furthermore, the longer the cells were stored, the lower the osteogenic differentiation capacity. In terms of the preservation media, excluding osterix, there were no significant differences between the $10 \%$ PRP group and the $0.9 \% \mathrm{NaCl}$ group. The expression of other genes was higher in the 10\% PRP and $10 \% \mathrm{HS}$ groups compared with the $0.9 \% \mathrm{NaCl}$ group (Fig. 8).

Osteocalcin and PPAR $\gamma$ protein expression is altered by ADSC preservation temperature, medium and duration. The protein expression of osteocalcin, which is involved in osteogenic differentiation, and PPAR $\gamma$, which is involved in adipogenic differentiation, was detected by western blotting. ADSCs stored at $4^{\circ} \mathrm{C}$ exhibited an increased expression of osteocalcin and PPAR $\gamma$ compared with those stored at RT (Fig. 9A and B). With increasing time, the expression of osteocalcin and PPAR $\gamma$ decreased (Fig. 9C and D). It was also observed that the secretion of osteocalcin and PPAR $\gamma$ was higher in the $10 \%$ PRP and $10 \%$ HS groups, compared with the $0.9 \% \mathrm{NaCl}$ group (Fig. 9E and F). 

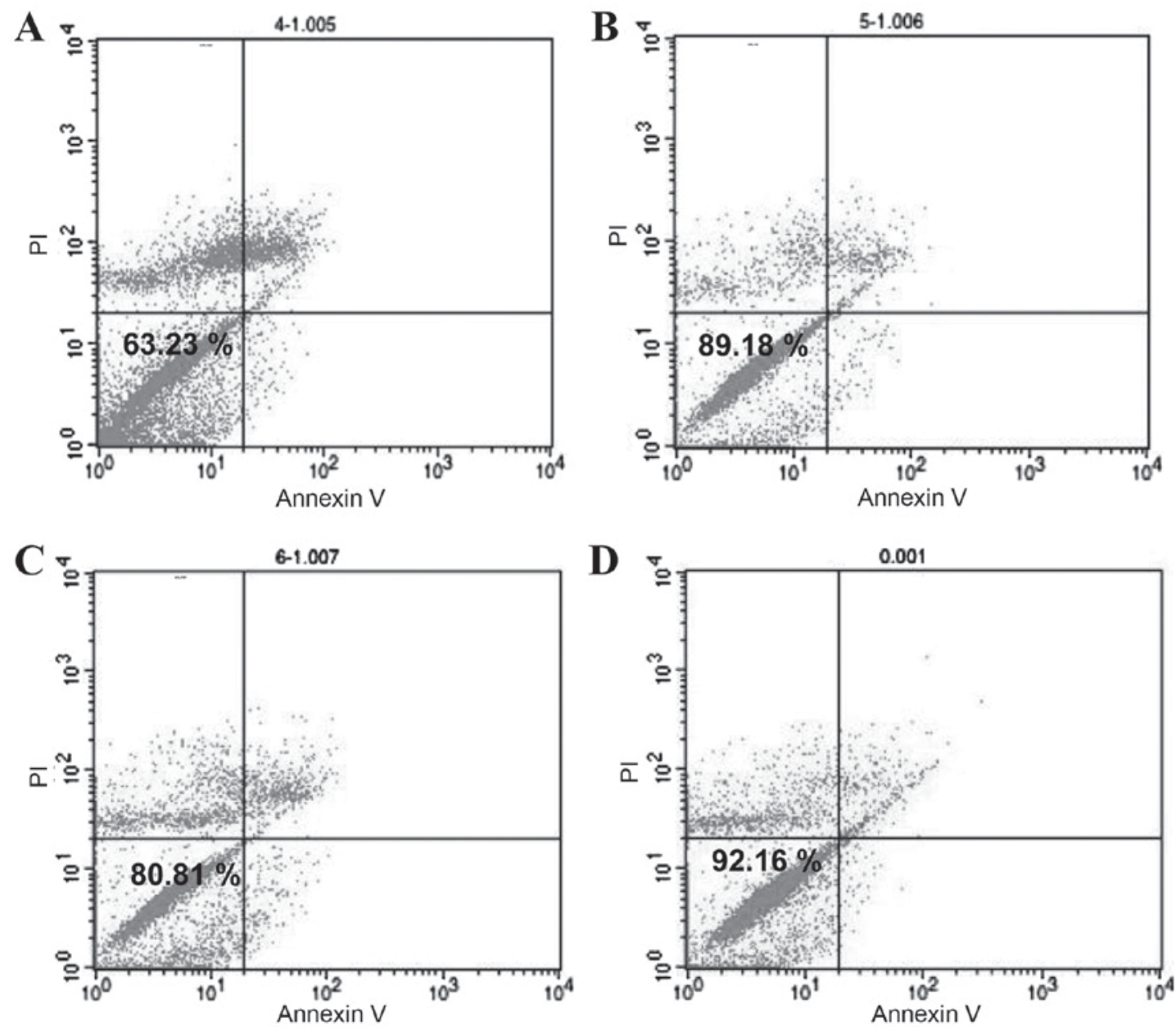

Figure 4. ADSC survival was determined by flow cytometry following preservation in $0.9 \% \mathrm{NaCl}, 10 \% \mathrm{HS}$ or $10 \%$ PRP for $2 \mathrm{~h}$. (A) ADSCs preserved in $0.9 \%$ $\mathrm{NaCl}$. (B) ADSCs preserved in 10\% HS. (C) ADSCs preserved in 10\% PRP. (D) Untreated ADSCs. "P<0.05. ADSCs, adipose-derived stem cells; HS, human serum; PRP, platelet-rich plasma; PI, propidium iodide.
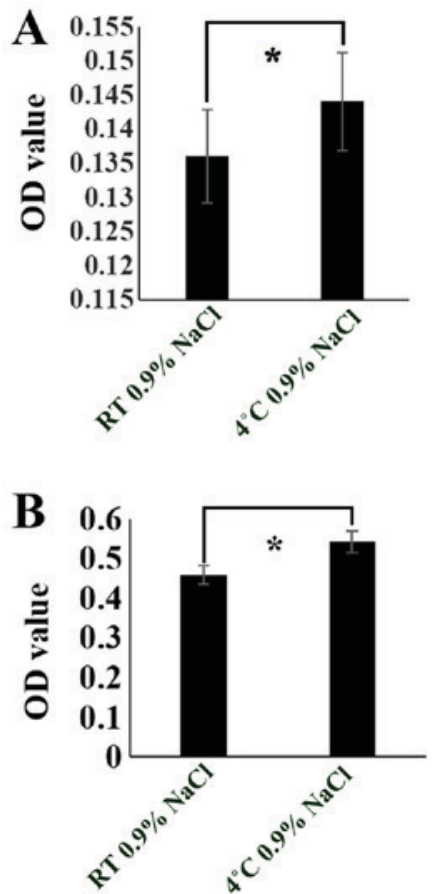

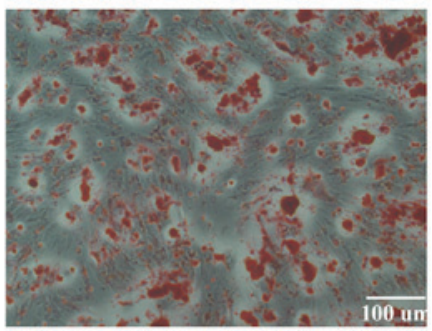

RT

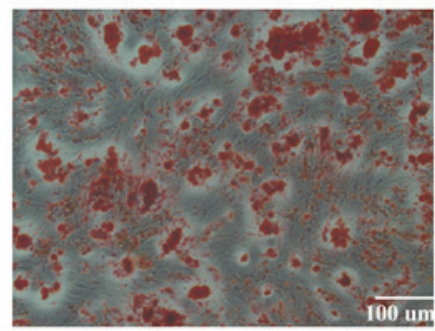

$4^{\circ} \mathrm{C}$

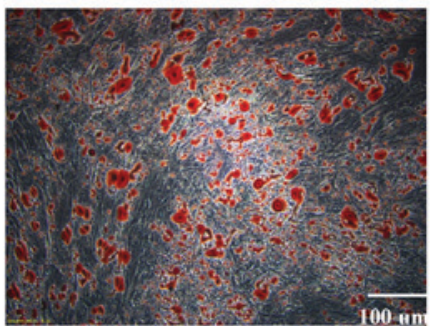

RT

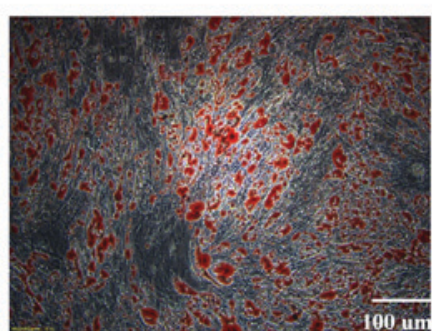

$4^{\circ} \mathrm{C}$

Figure 5. ADSCs from passage 2 were preserved in $0.9 \% \mathrm{NaCl}$ at $\mathrm{RT}$ or $4^{\circ} \mathrm{C}$ for $2 \mathrm{~h}$ to investigate the effects of temperature on the osteogenic and adipogenic differentiation capabilities. (A) The OD values of alizarin red $\mathrm{S}$ and (B) oil red $\mathrm{O}$ staining were determined in order to measure the degree of osteogenic and adipogenic differentiation, respectively. ${ }^{*} \mathrm{P}<0.05$. ADSCs, adipose-derived stem cells; RT, room temperature; OD, optical density. 
A

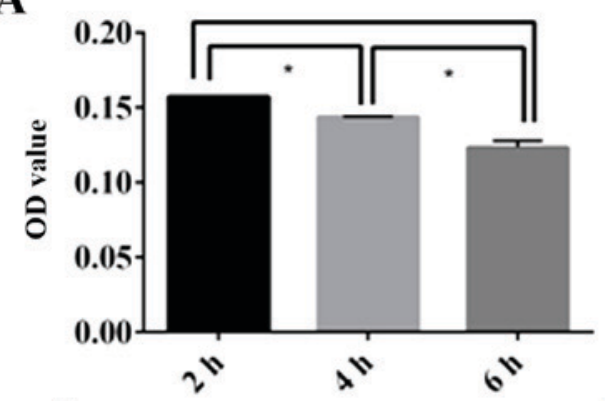

a-2

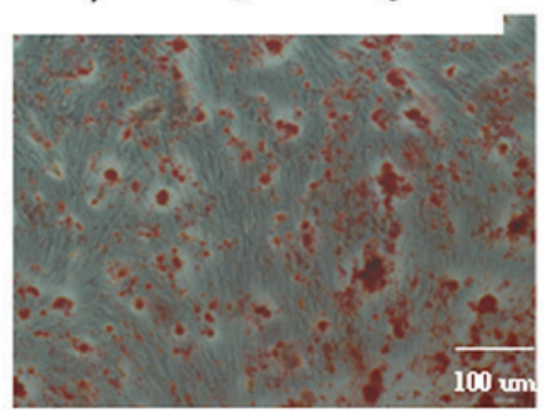

B

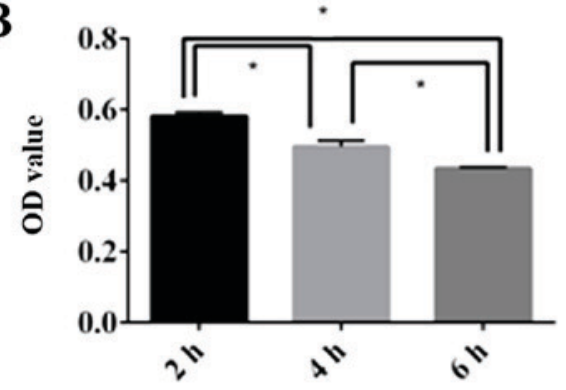

b-2

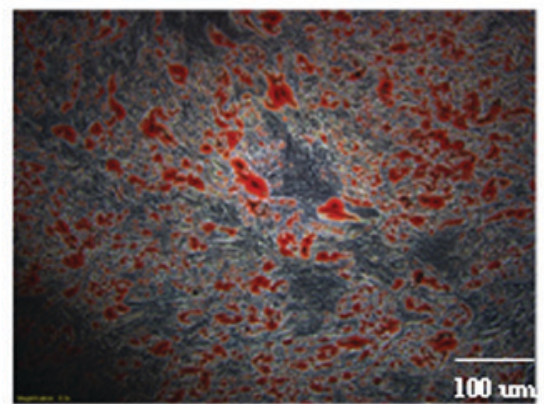

a-1

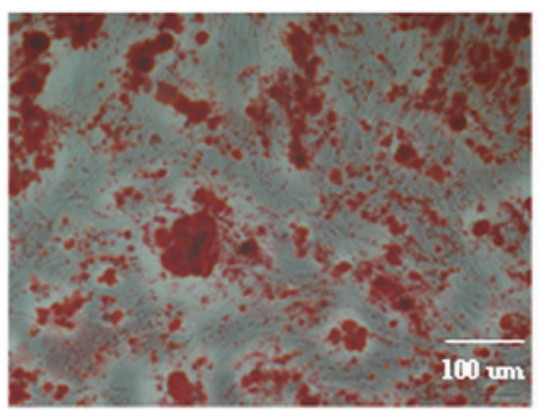

a-3

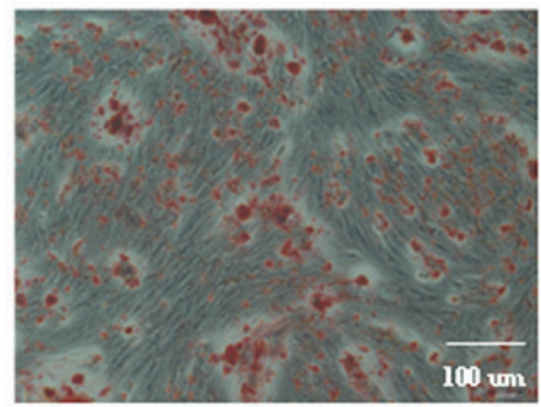

b-1

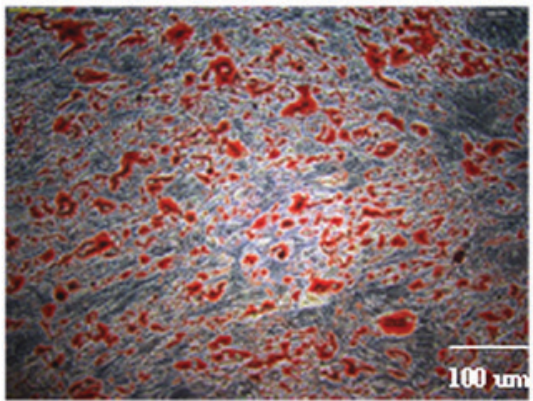

b-3

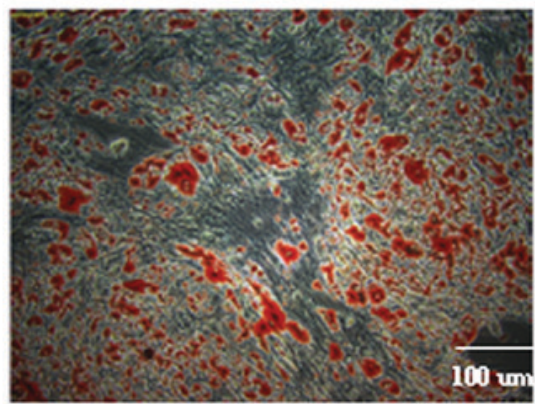

Figure 6. ADSCs from passage 2 were preserved in $0.9 \% \mathrm{NaCl}$ at $4^{\circ} \mathrm{C}$ for 2,4 and $6 \mathrm{~h}$ to investigate the effect of time on the osteogenic and adipogenic differentiation capabilities. (A) The OD values of alizarin red $\mathrm{S}$ and (B) oil red $\mathrm{O}$ staining were determined in order to measure the degree of osteogenic and adipogenic differentiation, respectively. "P<0.05. ADSCs, adipose-derived stem cells; OD, optical density.

\section{Discussion}

ADSCs are characterized by low immunogenicity and the adaptation of ADSCs to their environment provides a promising direction for future clinical applications (31). Martinez-Gonzalez et al (32), demonstrated that ADSCs protect the alveoli structure in patients with asthma by reducing the inflammation generated by neutrophil granulocytes, reducing IgE secretion and inhibiting lymphocyte infiltration. Additionally, Won et al (33) revealed that local injection of ADSCs promoted hair growth.

Several procedures are involved in the clinical preparation of ADSCs, including isolation, cultivation, passage and preservation. Especially in the preservation period, if, for instance, a patient has an accident, such as a sudden increased blood pressure or other cases that might affect the success of the surgery, a viable environment should be found to preserve the ADSCs.

PPAR $\gamma$ directly activates genes involved in lipid synthesis (34), and osteocalcin is a marker of osteogenic differentiation (35). The expression of RUNX2, SOX9 and osterix was detected to determine the osteogenic differentiation capacity of ADSCs stored under various conditions. FABP4, PPAR $\gamma$, and CEBP $\alpha$ expression was also detected to determine adipogenic differentiation capacity $(34,36-39)$. 
A

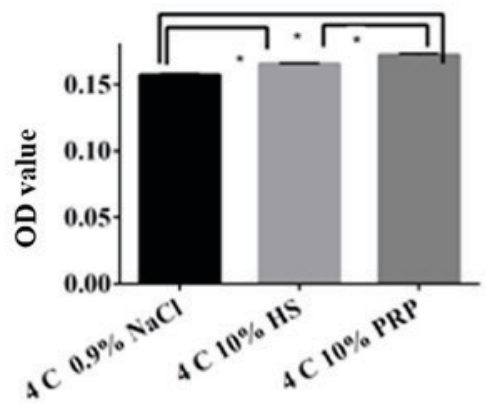

a-2

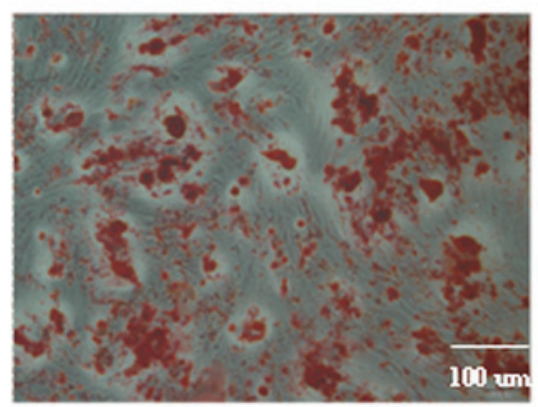

B
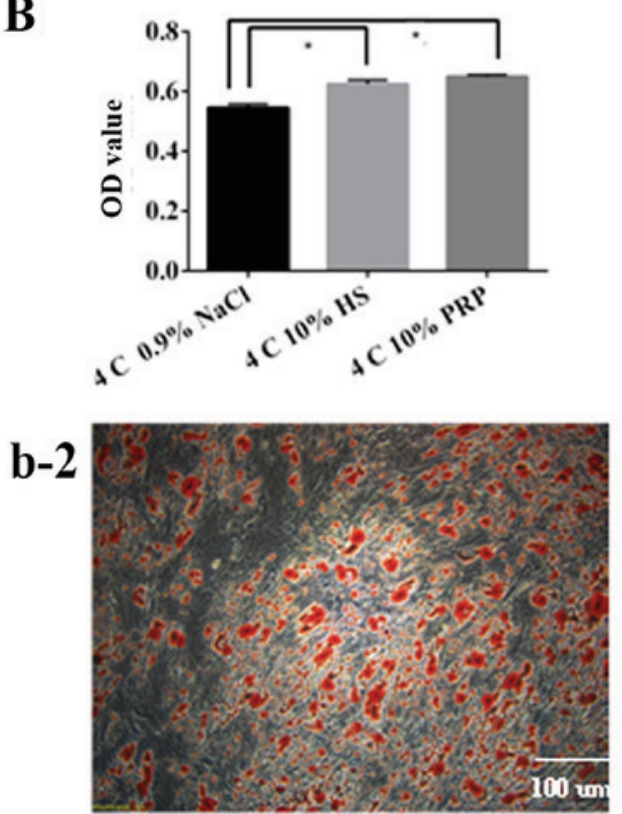

a-1

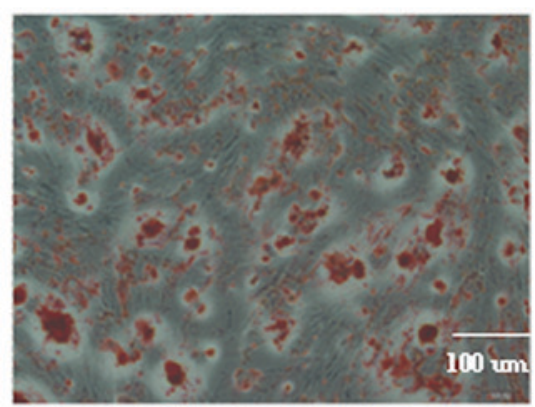

a-3

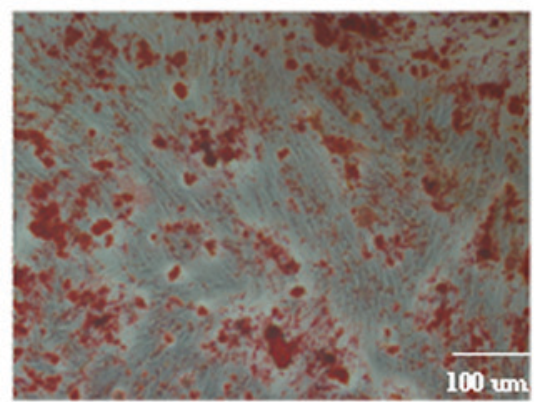

b-1

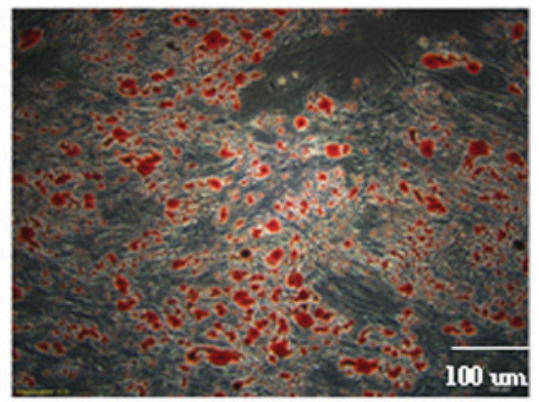

b-3

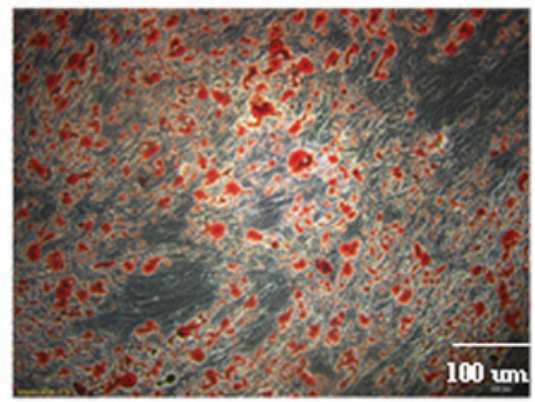

Figure 7. ADSCs from passage 2 were preserved in $0.9 \% \mathrm{NaCl}, 10 \% \mathrm{HS}$ and $10 \% \mathrm{PRP}$ at $4^{\circ} \mathrm{C}$ for $2 \mathrm{~h}$ to investigate the effects of these media on the osteogenic and adipogenic differentiation capabilities. (A) The OD values of alizarin red $\mathrm{S}$ and (B) oil red $\mathrm{O}$ staining were determined in order to measure the degree of osteogenic and adipogenic differentiation, respectively. ${ }^{*} \mathrm{P}<0.05$. ADSCs, adipose-derived stem cells; OD, optical density; HS, human serum; PRP, platelet-rich plasma.

According to the results of the present study, it was concluded that, compared with $\mathrm{RT}, 4^{\circ} \mathrm{C}$ was suitable as an appropriate temperature for ADSC storage. ADSCs preserved at $4{ }^{\circ} \mathrm{C}$ do not require cryoprotectant or a procedure for cell thawing, which avoids cryoprotectant toxicity and/or irreversible damage to the cell membrane (11). The results of the present study suggest that, in addition to temperature, the preservation medium also served an important role in the cell microenvironment. PRP and $\mathrm{HS}$ are both derived from patients here, and $\mathrm{NaCl}$ is also present in the body, which makes it a safer choice.

PRP is obtained from the patient's whole blood by concentrating the blood to a high platelet concentration $(40,41)$. PRP contains numerous growth factors, including platelet-derived growth factor, transforming growth factor- $\beta$, vascular endothelial growth factor and epidermal growth factor, which are delivered when PRP is activated (42-44). The results of the present study demonstrated that PRP improved osteogenic and adipogenic differentiation, which can be used to the fullest advantage, if necessary. PRP has been safely used in numerous fields, including oral and maxillofacial surgery, soft tissue ulcers, as well as stubborn acne and scar treatment $(41,43,45,46)$. The appropriate concentration of PRP for optimum cell proliferation and osteogenic differentiation was determined to be 10 and $12.5 \%$ by Liu et al (16). 

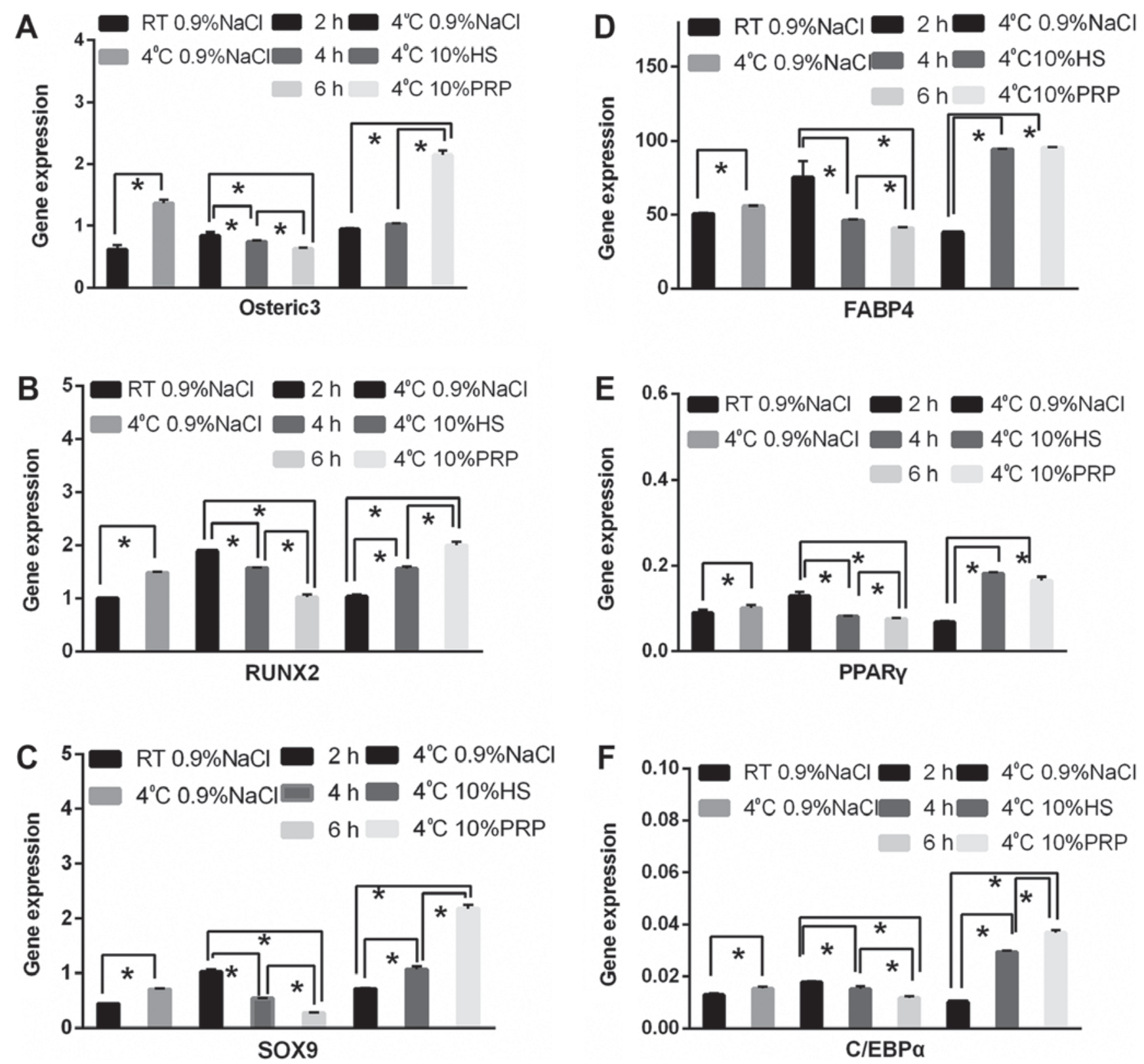

Figure 8. Expression of osteogenic and adipogenic-associated genes under different preservation conditions. Reverse transcription-quantitative polymerase chain reaction was performed to determine the gene expression levels of (A) osterix, (B) RUNX2, (C) SOX9, (D) FABP4, (E) PPAR $\gamma$, and (F) CEBP $\alpha$ among the different groups. "P<0.05. HS, human serum; PRP, platelet-rich plasma; RT, room temperature; osterix, sp7 transcription factor; RUNX2, runt-related transcription factor 2; SOX9, SRY-box 9; FABP4, fatty acid-binding protein 4; PPAR $\gamma$, peroxisome-proliferator-activated receptor $\gamma ;$ CEBP $\alpha$, CCAAT/enhancer binding protein $\alpha$.

HS is also obtained from the whole blood of patients, is safe for autologous use, and is abundantly available. Josh et al (47) used HS instead of FBS in the DMEM to demonstrate that HS is a viable alternative to FBS. As with adipose tissue, HS can be easily collected. As with PRP, HS also contains numerous growth factors, nutritive substances and other active factors, such as immunoglobulins, which may have a comprehensive effect on stem cell culture (48). For example, serum could provide nutrients needed for cell metabolism (49). Kobayashi et al (49) revealed that HS may be more optimal than FBS for human bone marrow growth.

In summary, $10 \%$ HS and 10\% PRP improved ADSC preservation. Compared with $10 \%$ PRP, $10 \%$ HS may be more optimal. This may be since HS has characteristics that approximate more closely to the normal ADSC environment, and therefore is more suitable for ADSC activity. Activated PRP releases growth factors that rapidly stimulate ADSC growth, and this may be perceived as a potential cause of the results obtained in the cell proliferation assay where PRP appears to have a higher OD value (Fig. 4B). Over time, ADSCs in the $10 \%$ PRP group appeared to be too undernourished to maintain normal growth. Based on these results, $10 \%$ HS may be the best choice for the preservation of ADSCs. In addition, from the same quantity of whole blood, a larger quantity of HS is obtained compared with PRP, and the process of retrieving HS is more convenient than that of PRP, which reduces the risk of infection (20). In conclusion, the storage of ADSCs at $4^{\circ} \mathrm{C}$ 
A

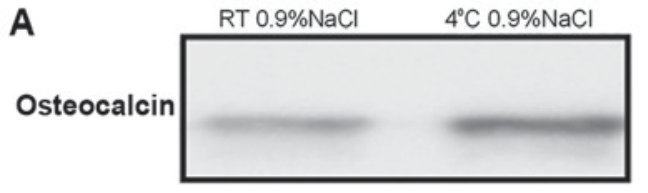

GAPDH

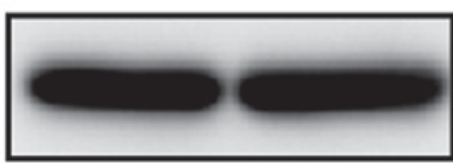

B
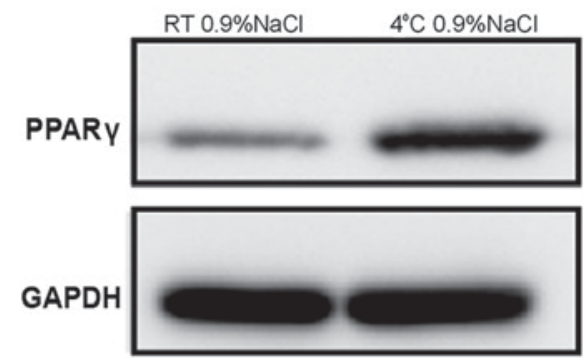

$2 \mathrm{~h}$
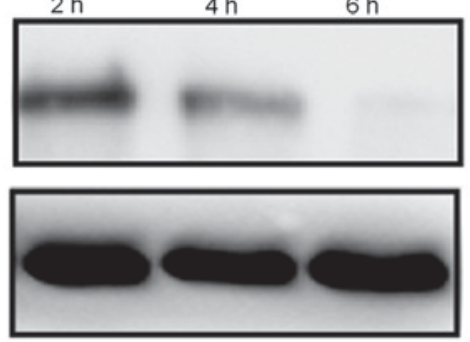

$6 \mathrm{~h}$
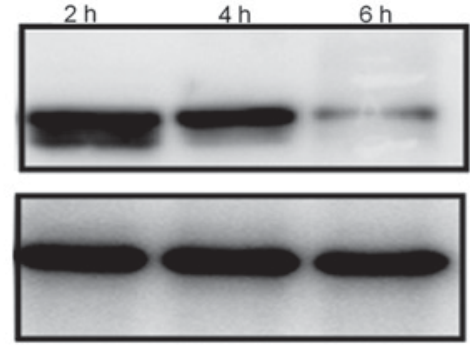

$0.9 \% \mathrm{NaCl}$
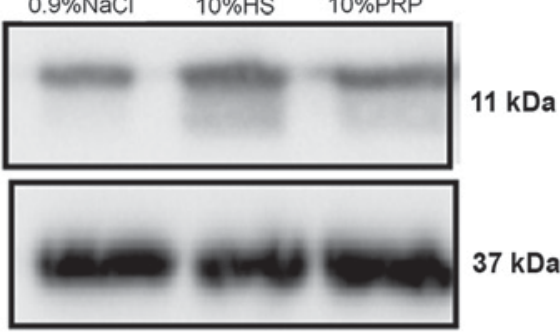

$37 \mathrm{kDa}$

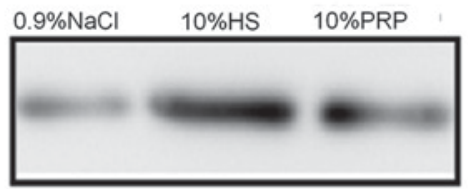

$58 \mathrm{kDa}$

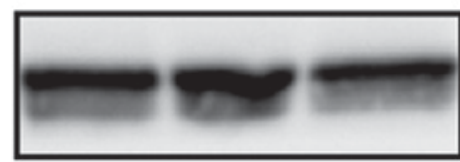

C

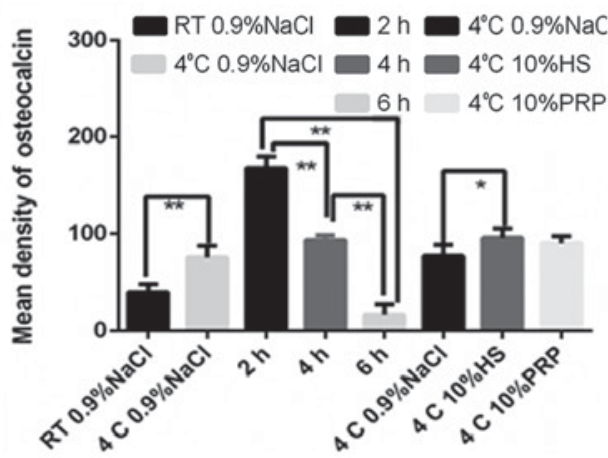

D

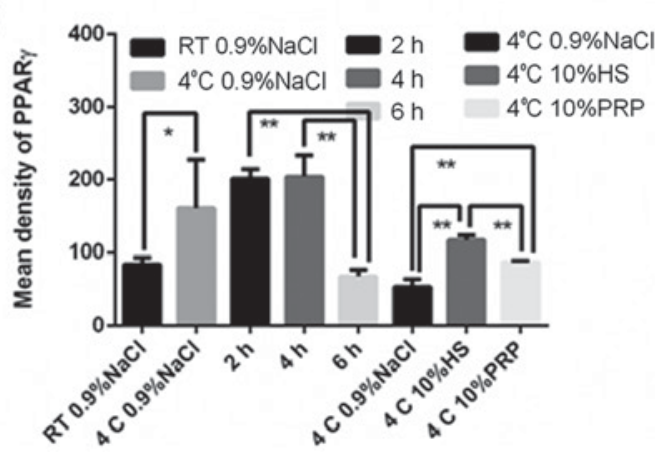

Figure 9. Expression of osteogenic and adipogenic-associated proteins under different preservation conditions. Western blot analysis of (A) osteocalcin and (B) PPAR $\gamma$ expression. (C) Densitometric analysis of osteocalcin and (D) protein expression in each condition. ${ }^{*} \mathrm{P}<0.05$, ${ }^{* *} \mathrm{P}<0.01$. HS, human serum; PRP, platelet-rich plasma; RT, room temperature; PPAR $\gamma$, peroxisome proliferator activated receptor $\gamma$.

in $10 \%$ HS was recommended. Furthermore, ADSCs should be used in $\leq 4 \mathrm{~h}$.

The survival rate and stability of ADSCs declined over time. Optimal preservation of ADSCs allows their function to be fully exerted upon their clinical use. ADSCs should be used in $<2 \mathrm{~h}$, and no later than $4 \mathrm{~h}$. If storage is required, $10 \% \mathrm{HS}$ at $4^{\circ} \mathrm{C}$ should be used. No differences were obtained between individuals in each experiment (data not shown).

Several problems remain when extensively using ADSCs. Standardization is required in order to apply ADSCs more safely and rationally, and equipment involving the separation and culture of ADSCs in clinical use should be optimized.

\section{Acknowledgements}

Not applicable

\section{Funding}

The present study was supported by the National Nature and Science Foundation,P.R.China (grant nos. 81272100, 81372065 and 81871563), the major project of Guangzhou Municipal Science and Technology Bureau (grant nos. 201300000091 and 201508020253), and the Natural Science Foundation of Guangdong, P.R. China (grant no. S2013010015264).

\section{Availability of data and materials}

The datasets used and/or analyzed during the current study are available from the corresponding author on reasonable request.

\section{Authors' contributions}

HL designed the study; YW and ML performed the experiments and wrote the manuscript; XL, SL, JY, LF, WS and JS analyzed the data.

\section{Ethics approval and consent to participate}

The protocol of the present study was approved by the Ethics Committee of The First Affiliated Hospital of Jinan University (Guangzhou, China). Informed consent was obtained from all subjects prior to study.

\section{Patient consent for publication}

Not applicable.

\section{Competing interests}

The authors declare that they have no competing interests. 


\section{References}

1. Gimble JM, Katz AJ and Bunnell BA: Adipose-derived stem cell for regenerative medicine. Circ Res 100: 1249-1260, 2007.

2. Bora P and Majumdar AS: Adipose tissue-derived stromal vascular fraction in regenerative medicine: A brief review on biology and translation. Stem Cell Res Ther 8: 145, 2017.

3. Gimble JM: Adipose tissue-derived therapeutics. Expert Opin Biol Ther 3: 705-713, 2003.

4. Baer PC and Geiger $\mathrm{H}$ : Adipose-derived mesenchymal stromal/stem cell: Tissue localization, characterization, and heterogeneity. Stem Cells Int 2012: 812693, 2012.

5. Qiu X, Fandel TM, Ferretti L, Albersen M, Orabi H, Zhang H, Lin G, Lin CS, Schroeder T and Lue TF: Both immediate and delayed intracavernous injection of autologous adipose-derived stromal vascular fraction enhances recovery of erectile function in a rat model of cavernous nerve injury. Eur Urol 62: 720-727, 2012

6. Lin G, Garcia M, Ning H, Banie L, Guo YL, Lue TF and Lin CS: Defining stem and progenitor cell within adipose tissue. Stem Cells Dev 17: 1053-1063, 2008.

7. Tobita M, Orbay $\mathrm{H}$ and Mizuno $\mathrm{H}$ : Adipose-derived stem cell: Current findings and future perspectives. Discov Med 11: 160-170, 2011.

8. Gonda K, Shigeura T, Sato T, Matsumoto D, Suga H, Inoue K, Aoi N, Kato H, Sato K, Murase S, et al: Preserved proliferative capacity and multipotency of human adipose-derived stem cell after long-term cryopreservation. Plast Reconstr Surg 121: 401-410, 2008.

9. Gonzalez-Fernandez ML, Perez-Castrillo S, Ordas-Fernandez P, Lopez-Gonzalez ME, Colaco B and Villar-Suarez V: Study on viability and chondrogenic differentiation of cryopreserved adipose tissue-derived mesenchymal stromal cell for future use in regenerative medicine. Cryobiology 71: 256-263, 2015.

10. Matsumoto D, Shigeura T, Sato K, Inoue K, Suga H, Kato H, Aoi N, Murase S, Gonda K and Yoshimura K: Influences of preservation at various temperatures on liposuction aspirates. Plast Reconstr Surg 120: 1510-1517, 2007.

11. Saragusty J and Arav A: Current progress in oocyte and embryo cryopreservation by slow freezing and vitrification. Reproduction 141: 1-19, 2011.

12. Saragusty J, Gacitua H, Rozenboim I and Arav A: Protective effects of iodixanol during bovine sperm cryopreservation. Theriogenology 71: 1425-1432, 2009.

13. Bunnell BA, Flaat M, Gagliardi C, Patel B and Ripoll C: Adipose-derived stem cell: Isolation, expansion and differentiation. Methods 45: 115-120, 2008.

14. Zhang F, Ren H, Shao X, Zhuang C, Chen Y and Qi N: Preservation media, durations and cell concentrations of short-term storage affect key features of human adipose-derived mesenchymal stem cells for therapeutic application. PeerJ 5: e3301, 2017.

15. Higman MA, Port JD, Beauchamp NJ Jr and Chen AR: Reversible leukoencephalopathy associated with re-infusion of DMSO preserved stem cell. Bone Marrow Transplant 26: 797-800, 2000

16. Liu Y, Zhou Y, Feng H, Ma GE and Ni Y: Injectable tissue-engineered bone composed of human adipose-derived stromal cell and platelet-rich plasma. Biomaterials 29: 3338-3345, 2008.

17. Shafaei H, Esmaeili A, Mardani M, Razavi S, Hashemibeni B, Nasr-Esfahani MH, Shiran MB and Esfandiari E: Effects of human placental serum on proliferation and morphology of human adipose tissue-derived stem cell. Bone Marrow Transplant 46: 1464-1471, 2011.

18. Jalowiec JM, D'Este M, Bara JJ, Denom J, Menzel U, Alini M, Verrier S and Herrmann M: An in vitro investigation of platelet-rich plasma-gel as a cell and growth factor delivery vehicle for tissue engineering. Tissue Eng Part C Methods 22: 49-58, 2016.

19. Weibrich G, Kleis WK, Hafner G and Hitzler WE: Growth factor levels in platelet-rich plasma and correlations with donor age, sex, and platelet count. J Craniomaxillofac Surg 30: 97-102, 2002.

20. Freymann U, Degrassi L, Kruger JP, Metzlaff S, Endres M and Petersen W: Effect of serum and platelet-rich plasma on human early or advanced degenerative meniscus cells. Connect Tissue Res 58: 509-519, 2017.

21. Bura A, Planat-Benard V, Bourin P, Silvestre JS, Gross F, Grolleau JL, Saint-Lebese B, Peyrafitte JA, Fleury S, Gadelorge M, et al: Phase I trial: The use of autologous cultured adipose-derived stroma/stem cell to treat patients with non-revascularizable critical limb ischemia. Cytotherapy 16: $245-257,2014$
22. Guo X, Li S, Ji Q, Lian R and Chen J: Enhanced viability and neural differential potential in poor post-thaw hADSCs by agarose multi-well dishes and spheroid culture. Hum Cell 28: 175-189, 2015.

23. Gu H, Guo F, Zhou X, Gong L, Zhang Y, Zhai W, Chen L, Cen L, Yin S, Chang $\mathrm{J}$ and Cui L: The stimulation of osteogenic differentiation of human adipose-derived stem cell by ionic products from akermanite dissolution via activation of the ERK pathway. Biomaterials 32: 7023-7033, 2011.

24. Wang J, Ye Y, Tian H, Yang S, Jin X, Tong W and Zhang Y: In vitro osteogenesis of human adipose-derived stem cell by coculture with human umbilical vein endothelial cell. Biochem Biophys Res Commun 412: 143-149, 2011.

25. Visweswaran M, Schiefer L, Arfuso F, Dilley RJ, Newsholme P and Dharmarajan A: Wnt antagonist secreted frizzled-related protein 4 upregulates adipogenic differentiation in human adipose tissue-derived mesenchymal stem cell. PLoS One 10: e118005, 2015

26. Li HX, Luo X, Liu RX, Yang YJ and Yang GS: Roles of Wnt/beta-catenin signaling in adipogenic differentiation potential of adipose-derived mesenchymal stem cell. Mol Cell Endocrinol 291: 116-124, 2008.

27. Samuel S, Ahmad RE, Ramasamy TS, Karunanithi P, Naveen SV Murali MR, Abbas AA and Kamarul T: Platelet-rich concentrate in serum free medium enhances osteogenic differentiation of bone marrow-derived human mesenchymal stromal cell. PeerJ 4: e2347, 2016.

28. Bunnell BA, Estes BT, Guilak F and Gimble JM: Differentiation of adipose stem cell. Methods Mol Biol 456: 155-171, 2008.

29. Wang X, Spandidos A, Wang H and Seed B: PrimerBank: A PCR primer database for quantitative gene expression analysis, 2012 update. Nucleic Acids Res 40: D1144-D1149, 2012.

30. Livak KJ and Schmittgen TD: Analysis of relative gene expression data using real-time quantitative PCR and the 2(-Delta Delta C(T)) method. Methods 25: 402-408, 2001.

31. Frese L, Dijkman PE and Hoerstrup SP: Adipose tissue-derived stem cells in regenerative medicine. Transfus Med Hemother 43: 268-274, 2016.

32. Martínez-González I, Cruz MJ, Moreno R, Morell F, Muñoz X and Aran JM: Human mesenchymal stem cell resolve airway inflammation, hyperreactivity, and histopathology in a mouse model of occupational asthma. Stem Cells Dev 23: 2352-2363, 2014.

33. Won CH, Yoo HG, Kwon OS, Sung MY, Kang YJ, Chung JH, Park BS, Sung JH, Kim WS and Kim KH: Hair growth promoting effects of adipose tissue-derived stem cell. J Dermatol Sci 57: 134-137, 2010.

34. Hernández-Bule ML, Martínez-Botas J, Trillo MÁ, Paíno CL and Úbeda A: Antiadipogenic effects of subthermal electric stimulation at $448 \mathrm{kHz}$ on differentiating human mesenchymal stem cells. Mol Med Rep 13: 3895-3903, 2016.

35. Rumiński S, Ostrowska B, Jaroszewicz J, Skirecki T, Włodarski K, Święszkowski W and Lewandowska-Szumieł M: Three-dimensional printed polycaprolactone-based scaffolds provide an advantageous environment for osteogenic differentiation of human adipose-derived stem cells. J Tissue Eng Regen Med 12: e473-e485, 2018.

36. Benazzo F, Botta L, Scaffino MF, Caliogna L, Marullo M, Fusi S and Gastaldi G: Trabecular titanium can induce in vitro osteogenic differentiation of human adipose derived stem cells without osteogenic factors. J Biomed Mater Res A 102: 2061-2071, 2014.

37. Rada T, Reis RL and Gomes ME: Distinct stem cells subpopulations isolated from human adipose tissue exhibit different chondrogenic and osteogenic differentiation potential. Stem Cell Rev 7: 64-76, 2011.

38. Smyth DC, Takenaka S, Yeung C and Richards CD: Oncostatin $\mathrm{M}$ regulates osteogenic differentiation of murine adipose-derived mesenchymal progenitor cells through a PKCdelta-dependent mechanism. Cell Tissue Res 360: 309-319, 2015.

39. Regassa A, Suh M, Datar J, Chen C and Kim WK: Fatty acids have different adipogenic differentiation potentials in stromal vascular cells isolated from abdominal fat in laying hens. Lipids 52: 513-522, 2017.

40. Nurden AT, Nurden P, Sanchez M, Andia I and Anitua E: Platelets and wound healing. Front Biosci 13: 3532-3548, 2008.

41. Whitman DH, Berry RL and Green DM: Platelet gel: An autologous alternative to fibrin glue with applications in oral and maxillofacial surgery. J Oral Maxillofac Surg 55: 1294-1299, 1997. 
42. Alsousou J, Thompson M, Hulley P, Noble A and Willett K: The biology of platelet-rich plasma and its application in trauma and orthopaedic surgery: A review of the literature. J Bone Joint Surg Br 91: 987-996, 2009.

43. Nikolidakis D and Jansen JA: The biology of platelet-rich plasma and its application in oral surgery: Literature review. Tissue Eng Part B Rev 14: 249-258, 2008.

44. Anitua E: Plasma rich in growth factors: Preliminary results of use in the preparation of future sites for implants. Int J Oral Maxillofac Implants 14: 529-535, 1999.

45. Drago L, Bortolin M, Vassena C, Romanò CL, Taschieri S and De Fabbro M: Plasma components and platelet activation are essential for the antimicrobial properties of autologous platelet-rich plasma: An in vitro study. PLoS One 9: e107813, 2014.

46. Margolis DJ, Kantor J, Santanna J, Strom BL and Berlin JA: Effectiveness of platelet releasate for the treatment of diabetic neuropathic foot ulcers. Diabetes Care 24: 483-488, 2001.
47. Josh F, Kobe K, Tobita M, Tanaka R, Suzuki K, Ono K, Hyakusoku $\mathrm{H}$ and Mizuno H: Accelerated and safe proliferation of human adipose-derived stem cell in medium supplemented with human serum. J Nippon Med Sch 79: 444-452, 2012.

48. Adkins JN, Varnum SM, Auberry KJ, Moore RJ, Angell NH, Smith RD, Springer DL and Pounds JG: Toward a human blood serum proteome: Analysis by multidimensional separation coupled with mass spectrometry. Mol Cell Proteomics 1: 947-955, 2002.

49. Kobayashi T, Watanabe H, Yanagawa T, Tsutsumi S, Kayakabe M, Shinozaki T, Higuchi H and Takagishi K: Motility and growth of human bone-marrow mesenchymal stem cell during ex vivo expansion in autologous serum. J Bone Joint Surg Br 87: 1426-1433, 2005.

This work is licensed under a Creative Commons Attribution-NonCommercial-NoDerivatives 4.0 International (CC BY-NC-ND 4.0) License. 